International Journal of Agriculture and Envrionmental Research

ISSN: 2455-6939

Volume: 06, Issue: 05 "September-October 2020"

\title{
ALLELOPATHIC EFFECT OF CORN ON COFFEE DEVELOPMENT
}

\author{
${ }^{1}$ Rodrigo P. MARIANO, ${ }^{2}$ Kleso S. F. JUNIOR, ${ }^{3}$ Daniel Gonçalves Siqueira, \\ ${ }^{4}$ Giselle P. BRIGANTE, ${ }^{5}$ Marcio de SOUZA DIAS \\ ${ }^{1,3}$ Academic of the CESEP agronomy course. \\ Higher education and research center of MACHADO MG. \\ ${ }^{2}$ Teacher/doctor, Faculty of agronomy CESEP. \\ Higher education and research center of MACHADO MG. \\ ${ }^{4}$ Teacher/doctor, A coordinator of the faculty of agronomy CESEP. \\ Higher education and research center of MACHADO MG. \\ ${ }^{5}$ Teacher/doctor, Secretary of Education of the State of MG.
}

DOI: https://doi.org/10.51193/IJAER.2020.6504

\begin{abstract}
Consortium cultivation of coffee and maize crops, interspersed between the lines, is a common and traditional practice, mainly for small producers and family farming, with them a in destinations being to assist in the income of the property, to supplement human food as well as to the animal. However, there are many doubts about the relationship between the allelopathic effects or the competition between corn and coffee, caused by the cultivation of corn, mainly in the initial development phase of coffee. Thus, the research aimed to evaluate the allelopathic effect of corn hybrids on the initial development of coffee. The study was conducted in Poço Fundo (MG), with Arabica coffee seedlings of the cultivar Arara in polyethylene pots, and the corn hybrids, treatments, were Dekalb 3700RR2, Biomatriz Grifos, Biomatrix 207, and, Zeamays, with applications of $8 \mathrm{~g} / \mathrm{L}$ mixtures extracted from the hybrids. It can be concluded that the corn hybrids resulted in allelopathy on the coffee tree, inhibiting the growth in relation to the aerial part, root, weight of fresh and dry matter, as well as the leaf area index of the coffee tree.
\end{abstract}

Keywords: Coffeaarabica, Inhibitor, Zeamays.

\section{INTRODUCTION}

Brazil has been producing coffee for almost three centuries, a crop which spread throughout the territory and grew considerably to become the main product of the Brazilian economy in the period of the Old Republic (1894 - 1930) (ABIC, 2020) and is currently present as one of the 
International Journal of Agriculture and Envrionmental Research

ISSN: 2455-6939

Volume: 06, Issue: 05 "September-October 2020"

main products of the Brazilian economy, mainly for having a great participation in the foreign market, being considered as the second largest commodity generating wealth of the planet (DAVIRON; PONTE, 2005; MARCOLAN; ESPINDULA, 2015; PARTELLI; BONOMO, 2016).

In the 2019 harvest, Brazil achieved a total coffee production of 49,31 million bags of coffee benefited and having a productivity of 27.20 bags per hectare (CONAB, 2019). However, the country has two main species of the crop, namely Arabica coffee and Robusta coffee (MACHADO et al., 2020), and of these species, the most expressive, in terms of production and planting, is the Arabica coffee, which represents more than $70 \%$ of the country's production estimate (CONAB, 2019). Such production extends throughout the Brazilian territory, with the state of Minas Gerais standing out as the center of coffee in Brazil, due to having 57,70\% of the entire Brazilian coffee area (CONAB, 2019).

However, coffee plantations require numerous cultural treatments to obtain productivity and quality. For the development of coffee trees care must be taken, especially with the preparation and correction of soil acidity, fertilization, in order to improve development and have healthy and well-stabilized plants. In addition to these cultural treatments, another widely used is the intercalation of crops with coffee, aiming at breaking the wind and ensuring the avoidance of pathologies and certain pests, aliases, intercalating cultures are also used for the incorporation of nutrients into the soil and as well as a source of auxiliary income. However, such practices have disadvantages, such as being a refuge for pests, causing competition for nutrients and water, as well as producing allelochemical substances (MESQUITA, 2016). Being such allelopathic issues of great attention within the succession cultivation, such biochemical reactions can harm or assist in the development of cultures, when occurring in large quantities, generating negative interferences for the development of plants, and when occurring in small quantities, add benefits and help the growth and development of plants (FRANÇA, 2007).

In Minas Gerais, specifically in the south of the state, the soil has excellent fertility characteristics and it is common for producers, because they are small, to plant some crops, such as corn, being exploited as an activity for financial return and as also for human and animal food. The fact that the crop has an annual cycle, it is possible to perform a cycle of nutrients, presenting a large percentage in the production of dry matter to the soil, which may be contributing to the cultivation of coffee, as it is a perennial crop whose cultivation it will be implanted for longer.

However, there are reports that the establishment and development of coffee in areas that were destined for the planting of corn and / or that contain crop residues, present harm to the entire 
International Journal of Agriculture and Envrionmental Research

ISSN: 2455-6939

Volume: 06, Issue: 05 "September-October 2020"

cycle of development of the coffee tree (FRANCE et al., 2006), in this way, aimed to evaluate the allelopathic effect of corn hybrids on the initial formation of coffee.

\section{MATERIAL AND METHODS}

The experiment was carried out from January to June 2020 at site "X", located in the

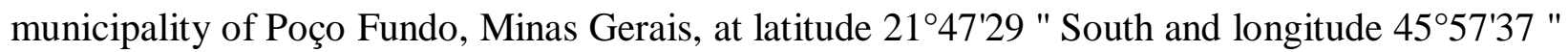
West, at an altitude of 810 meters above sea level, having hot temperate climatic characteristics, whose temperature varies from $7{ }^{\circ} \mathrm{C}$ to $27{ }^{\circ} \mathrm{C}$ and has an annual average of $20,4{ }^{\circ} \mathrm{C}$ (CLIMATEMPO, 2020).

The design used was randomized blocks (DBC), with four treatments, being: control, hybrid extract Dekalb 3700 RR2; Biomatrix Grifos extract; biomatrix 207 extract; with five replications, totaling 20 experimental plots.

For the study, it was used the cultivar of Arabica coffee Arara, for presenting patterns of size and quantity of leaves, in a more homogeneous way. The seedlings obtained had five pairs of leaves and registered quality according to the standards of the National Register of Seeds and Seedlings (RENASEM) (FRANCE, 2007), and were transplanted in polyethylene pots with a capacity of $30 \mathrm{dm}^{3}$ manually. Soil $\mathrm{pH}$ correction was carried out by applying $100 \mathrm{~g}$ of dolomitic lime stone with 85\% PRNT and then adding water and leaving it for incubation for 30 days to correct the acidity of the soil. After a period, tanned bovine manure was added to the soil in the proportion of 50L of manure for each 150L of soil. Finally, performing fertilization, using $100 \mathrm{~g}$ in each portion of organomineral fertilization formulation 02-10-00. Seedling transplantation took place in March / 2020, after 30 days of planting, covering fertilizer, 40g of ammonium sulfate (21-0000) was applied; and, after 49 days after planting, the extract of the corn hybrids was applied.

The extract was obtained by collecting ears of the hybrids in the field, when the plants were in the $\mathrm{R} 4$ reproductive stages, which happens 20 to 25 days after the emission of the flora tassel. It is noteworthy that this period is where a great accumulation of starch occurs in the grains, in addition to the consistency going from milky to pasty and the embryonic structures are totally differentiated (EMBRAPA, 2010). Then, the processing was carried out to obtain the extract, using a Nogueira DPM2 ensiler, and then the samples were placed in a blender (World Model 750 watts) with $500 \mathrm{~mL}$ of distilled water and $400 \mathrm{~g}$ of the crushed hybrids, resulting in a liter of extract. Then, $500 \mathrm{~mL}$ of the extract was applied to each portion of the soil, using a sprayer (Guarany Model) with a capacity of $500 \mathrm{~mL}$.

After 120 days of planting, the following coffee parameters were evaluated: root system length $(\mathrm{cm})$; aerial part height $(\mathrm{cm})$; fresh matter weight $(\mathrm{g})$; dry matter weight $(\mathrm{g})$; leaf area index (IAF) using the formula $\mathrm{C} \times \mathrm{W} \times 0.677$ (BARROS et al., 1973). The data obtained were 
submitted to statistical analysis using the SISVAR® software (FERREIRA, 2014), the significant difference between treatments being determined by the $\mathrm{F}$ test, with the means compared by the Scott-Knott test atthe $5 \%$ probability level.

\section{RESULTS AND DISCUSSIONS}

After the application of the experiment and with the seedlings completing 120 days of planting, the data referring to the growth of the area and root part was evaluated as expressed in Table 1.

Table 1: Influence of corn extract on the initial development of coffee.

\begin{tabular}{|c|c|c|c|c|c|c|c|c|}
\hline \multirow{2}{*}{$\begin{array}{l}\text { Parameters } \\
\text { Leaf Area } \\
\text { Length }(\mathrm{cm})\end{array}$} & \multicolumn{2}{|c|}{$\begin{array}{c}\text { Treatment } 1 \\
\text { Dekalb } 3700 R R 2\end{array}$} & \multicolumn{2}{|c|}{$\begin{array}{l}\text { Treatment } 2 \\
\text { Biomatrix Grifos }\end{array}$} & \multicolumn{2}{|c|}{$\begin{array}{l}\text { Treatment } 3 \\
\text { Biomatrix } 207\end{array}$} & \multicolumn{2}{|c|}{$\begin{array}{l}\text { Treatment } 4 \\
\text { Control }\end{array}$} \\
\hline & 30,5 & A & 30,2 & A & 30,0 & A & 30,4 & A \\
\hline $\begin{array}{l}\text { Root System } \\
\text { Length }(\mathrm{cm})\end{array}$ & 21,2 & B & 20,9 & B & 18,8 & $\mathrm{C}$ & 22,5 & A \\
\hline $\begin{array}{l}\text { Total length } \\
(\mathrm{cm})\end{array}$ & 51,7 & A & 51,1 & B & 48,8 & $\mathrm{C}$ & 52,9 & A \\
\hline $\begin{array}{l}\text { Fresh Dough } \\
\text { Weight }(g)\end{array}$ & 14,3 & B & 12,0 & $\mathrm{C}$ & 13,2 & B & 16,9 & $\mathrm{~A}$ \\
\hline $\begin{array}{l}\text { Dry Mass } \\
\text { Weight }(g)\end{array}$ & 3,2 & B & 2,4 & $\mathrm{C}$ & 2,0 & $\mathrm{C}$ & 4,1 & A \\
\hline $\begin{array}{l}\text { Leaf Area Index } \\
\left(\mathrm{cm}^{2}\right)\end{array}$ & 260,5 & B & 252,6 & B & 112,5 & $\mathrm{C}$ & 292,6 & A \\
\hline \multicolumn{9}{|c|}{$\begin{array}{l}\text { Means followed by equal letters on the line, do not differ significantly by the Scott-Knotttest in } \\
\text { the } 5 \% \text { probability. }\end{array}$} \\
\hline \multicolumn{9}{|c|}{$\begin{array}{l}\text { The Leaf Area Index showed a statistically significant difference }(\mathrm{p}<0.05) \text {, where the initial } \\
\text { development of the coffee tree was lower with the stratum of the hybrid Biomatrix } 207 \text {, } \\
\text { presenting an IAF of } 112,5 \mathrm{~cm}^{2} \text {. The } 3700 \text { RR } 2 \text { hybrids and the Biomatrix Grifos hybrid had } \\
\text { lower results than the control, as shown in Table } 1 \text {. }\end{array}$} \\
\hline \multicolumn{9}{|c|}{$\begin{array}{l}\text { In the study by França (2007), it was concluded that the chlorophyll content presented in the } \\
\text { Arabica coffee cultivars Topázio, Rubi, Catuai and Catucai, had variation in the production of }\end{array}$} \\
\hline www.ijaer.in & \multicolumn{6}{|c|}{ Copyright @ IJAER 2020, All rights reserved } & \multicolumn{2}{|c|}{ Page 703} \\
\hline
\end{tabular}


International Journal of Agriculture and Envrionmental Research

ISSN: 2455-6939

Volume: 06, Issue: 05 "September-October 2020"

chlorophyll resulting from the hybrids incorporated in the soil used, where each cultivar responded in a different way. Different for each corn hybrid used. The leaf area of the crop is of great importance, due to the fact that they perform gas exchanges, are light receptors for conversion to chlorophyll, but the most important activity is the photosynthetic capacity, where the plant receives light energy and transforms it into chemical energy, occurring the production of adenosine triphosphate (ATP), which are used to produce enzymes which are distributed in the plant to form leaves, roots, flowers and fruits (FAVARIN, 2005).

As for the root system, it is observed that the hybrid Biomatrix 207 differed statistically from the others, showing an allelopathic effect on the root development of coffee in its initial phase. The Biomatrix Grifos and Dekalb 3700 RR2 hybrids differed statistically in relation to the control.

Regarding the weight of fresh pasta, the treatments that received applications of the extract differed statistically from the control treatment, mainly Treatment 2 , which had an average of 12,0 grams. Results achieved in the research of França (2007), corroborate with the data obtained, where different accumulations of stembiomass occurred in each coffee cultivar, they respond differently for each hybrid used with the cultivar Topázio which has a greater accumulation of biomass when used the hybrid GNZ2004 and the cultivar Catucailess accumulation when the hybrid DKB350 is used as in corporation into the soil. The amount of hybrid biomass in relation to the soil directly influences the allelopathic effects in relation to coffee, and low concentrations encourage growth or inhibit it (SANTOS, 2003). The roots of the coffee tree have the purpose of accumulating nutrients, sustaining the plant, absorbing nutrients and water, in addition, the root system determines the growth of the aerial part for the reasons mentioned.

The parameters involving the weight of drymass, it is noted that the Biomatrix hybrids showed a statistical difference from the other treatments, with the control treatment having the best result. Again, the weight of the dry matter proves the allelopathic effect caused by the corn crop in the initial development of the coffee tree.

Plants have secondary systems that produce metabolites that act as allelopathies, but since all plants have different cultivars and hybrids, they respond differently to these metabolites, where each one produces different amounts that may represent different results (FERREIRA; AQUILA, 2000).

Specifically for corn, studies show that it causes allelopathic effects in other crops, in the case of lettuce, it causes delayed germination in an area that has corn residues in the soil (FRANÇA, 2007). 
International Journal of Agriculture and Envrionmental Research

ISSN: 2455-6939

Volume: 06, Issue: 05 "September-October 2020"

\section{CONCLUSION}

It was concluded that the extracts of the corn hybrids Dekalb 3700 RR2, Biomatrix Grifos and Biomatrix 207 exceeded allelopathy in coffee development, reducing the parameters of the plant's root and aerial system, as well as the leaf area index.

\section{REFERENCES}

ABIC - ASSOCIAÇÃO BRASILEIRA DA INDUSTRIA DO CAFÉ. História do café. 2020. Disponível em: <https://www.abic.com.br/o-cafe/historia/>. Acesso em: 15 de ago. 2020

BARROS, R.S.; MAESTRI, M.; VIEIRA, J.; BRAGA FILHO, L.J. Determinação da área foliar do café (Coffea arábica L. cv. 'Bourbon Amarelo'). Revista Ceres, Viçosa, v.20, n.107, p.44-52, $1973 . \quad$ Disponível em: http://www.conhecer.org.br/enciclop/2011b/ciencias\%20agrarias/metodos.pdf. Acesso em 03 set. 2020.

CLIMATEMPO. Climatempo News ao vivo. Disponível em: <http://www.climatempo.com.br/videos/ao-vivo>. Acesso em: 03 set. 2020.

CONAB - COMPANHIA NACIONAL DE ABASTECIMENTO. Acompanhamento da safra brasileira - café. CONAB, $4^{\circ}$ ed., 2019. Disponível em <https://www.conab.gov.br/infoagro/safras/cafe>. Acessoem: 12 de ago. 2020.

DAVIRON, B. AND PONTE, S. (2005). The Coffee Paradox: Commodity Trade and the Elusive Promise of Development. London, UK: Zed Books

EMBRAPA. Cultivo do milho. Sete Lagoas: Embrapa Milho e Sorgo, 2010.

FAVARIN J.L.; NETO D.D.; GARCIA A.; NOVA N.A.V.; FAVARIN M.G.G.V. Equações para estimativa do índice de área foliar do cafeeiro. Brasília june, v.37, n.6, 2002. Escola Superior de Agricultura Luiz Queiroz, São Paulo.

FERREIRA, D.F. Sisvar: um guia dos seus procedimentos de comparações múltiplas Bootstrap. Ciência e Agrotecnologia; v.38-2p. 109-112,2014. Acesso em: 03 set. 2020.

FERREIRA A.; AQUILA M. Alelopátia: uma área emergente da ecofisiologia. 2000.176p. Departamento de Botânica, Universidade de Brasília e Laboratório de Fisiologia Vegetal, Universidade Federal do Rio Grande do Sul.

FRANÇA A. C; Potencial Alelopátio de Híbrido de milho no desenvolvimento inicial do cafeeiro. 2007.20p.Lavras, Minas Gerais. 
FRANÇA A.; SOUZA I.; ALVES L.; JESUS A. Potencial Alelopátio de Híbrido de milho no desenvolvimento inicial do cafeeiro. 2006.27p. Lavras, Minas Gerais.

MACHADO, A. H. R. et al. A Cultura do Café (Coffeaarabica) em Sistema Agroflorestal. Brazilian Journal of Animal and Environmental Research, v. 3, n. 3, p. 1357-1369, 2020.

MARCOlan, A. L.; ESPINDUlA, M. C. Café na Amazônia. Rondônia, Brasil: Embrapa, 2015

MESQUITA C.M.; MELO E.M.; REZENDE J.E.; CARVALHO J.S.; JÚNIOR M.A.F.; MORAIS N.C.; Dias P.T.; CARVALHO E.M.; ARAÚJO W.G.; Manual do Café: Implantação de cafezais.2016.45p. Belo Horizonte, Minas Gerais.

PARTELli, F. L.; BONOMO, R. Café conilon: O clima e o manejo da planta. Alegre, Espírito Santos, Brasil: Caufes, 2016

SANTOS C.C; SOUZA I.F.; ALVES L.W.R. Efeitos de Restos Culturais de Milho Sobre o Crescimento de Plantas de Cafeeiro. 2003.6p. Lavras, Minas Gerais. 